\title{
Carcass Characteristics and Bone Measurements of Commercial Broilers Fed with Inorganic, Organic and Nano Zn Containing Diets
}

\author{
A. $\operatorname{Varun}^{1 *}$ N. Karthikeyan ${ }^{1}$, P. Muthusamy ${ }^{2}$, A. Raja ${ }^{3}$, \\ S. Wilfred Ruban ${ }^{4}$ and J. Tamilkumaran ${ }^{5}$ \\ ${ }^{1}$ Department of Poultry Science, Madras Veterinary College, Chennai, Tamil Nadu, India \\ ${ }^{2}$ Post Graduate Research Institute in Animal Sciences, TANUVAS, Kattupakkam, \\ Tamil Nadu, India \\ ${ }^{3}$ Department of Microbiology, VCRI, Namakkal, Tamil Nadu, India \\ ${ }^{4}$ Department of Livestock Product Technology, Veterinary College, Bengaluru, Karnataka, India \\ ${ }^{5}$ Department of veterinary Extension, RIVER, Puducherry, India \\ *Corresponding author
}

\section{A B S T R A C T}

The present study was conducted to investigate the effect of dietary supplementations of inorganic, organic and nano $\mathrm{Zn}$ on carcass characteristics and bone morphometric study in

Keywords

Caracass

characteristics,

inorganic,

organic, nano $\mathrm{Zn}$,

vencobb broilers

Article Info

Accepted:

31 July 2017

Available Online:

10 September 2017 broiler chickens. A total of 300 day-old straight run broiler chicken were randomly assigned to 10 dietary treatments each consisting of 3 replicates and each replicate having 10 chicks for a period of 6 weeks. The dietary treatments includes corn-soybean meal based basal diet as control $\left(\mathrm{T}_{1}\right)$ or the basal diet supplemented either with 40 or $80 \mathrm{mg}$ of $\mathrm{Zn} / \mathrm{kg}$ of feed from each sources, such as $\mathrm{Zn}$ oxide $\left(\mathrm{T}_{2}\right.$ and $\left.\mathrm{T}_{3}\right), \mathrm{Zn}$ sulphate $\left(\mathrm{T}_{4}\right.$ and $\left.\mathrm{T}_{5}\right)$, $\mathrm{Zn}$-methionine $\left(\mathrm{T}_{6}\right.$ and $\left.\mathrm{T}_{7}\right)$ and $\mathrm{Zn}$-protienate $\left(\mathrm{T}_{8}\right.$ and $\left.\mathrm{T}_{9}\right)$ except that the nano-Zn which was supplemented only at $20 \mathrm{mg} / \mathrm{kg}\left(\mathrm{T}_{10}\right)$. At the day 42 , two birds from each replicate were taken randomly for the slaughter study. The highest eviscerated weight $(\%)$ observed in the group fed with $40 \mathrm{mg} \mathrm{Zn}$-protienate $\left(\mathrm{T}_{8}\right)$ which was non-significant $(\mathrm{p}>0.05)$. Ready-to-cook yield, cut-up parts and giblet $(\%)$ did not show any significant $(p>0.05)$ difference between experimental groups. Regarding bone morphometric parameters such as bone weight, length and width, a non-significant ( $p>0.05$ ) difference exist among the treatment groups. It was concluded that the dietary inclusion of inorganic, organic and nano $\mathrm{Zn}$ did not show any significant difference on the carcass yields and bone morphometric parameters.

\section{Introduction}

Indian Poultry Industry is one of the fastest growing segments of the agricultural sector today in India. India's poultry sector is likely to see huge growth potential because of stable feed prices and encouraging rural demand, resistance to local and global challenges including a recent outbreak of bird flu and threat of chicken-leg imports from the US. India is the third largest broiler-chicken producer in the world with production of 3.8 million tonne of poultry meat a year (Raji Reddi Kesireddy, 2014). Minerals occur naturally in most feed ingredients with varying bioavailability. 
Trace minerals like zinc is essential for broiler growth and are involved in many digestive, physiological and biosynthetic processes. They are constituents of many proteins involved in intermediary metabolism, hormone secretion pathways and immune defense systems. The trace mineral supplementation of poultry diets is usually accomplished with inorganic sources (Bao et al., 2007). Excessive use of inorganic salts leads to reduced nutrients absorption and mineral bioavailability. In addition, excessive mineral intake causes environmental pollution by higher mineral excretion.

These excess minerals can leach through soils, potentially contaminating surface and underground water supplies (Jackson et al., 2003). Due to increasing concerns about potential mineral pollution, nutritionists have been focused on how to reduce mineral excretion without any negative effect on production performance (Devrim et al., 2010). Organically complexed trace minerals may provide alternative pathways for absorption, by decreasing mineral excretion (Leeson, 2003).

These types of minerals are more easily absorbed compared to inorganic forms. Due to chelation of metal ions with organic substances this makes these metal ions electrically neutral and chemically stable, thereby allowing easy passage through the small intestinal wall. Nano zinc oxide $(\mathrm{nZnO})$ is a new form of mineral presentation that has been produced and marketed using concepts of nano science and technologies (Song et al., 2010).

Hence, with this background the present study was conducted to investigate and compare the effect of different available forms of zinc (inorganic, organic and nano) on the carcass traits and bone morphometric parameters in the commercial broiler chicken.

\section{Materials and Methods}

\section{Ethical approval}

The experiment was carried out as per the guidelines of the National Regulations on Animal Welfare and Institutional Animal Ethics Committee. The experiment was carried out in the Department of Poultry Science, Madras Veterinary College, TANUVAS, Chennai, Tamil Nadu, India. A total of 300 day-old straight run vencobb 400 broiler chicks were procured from a franchise (Swami feeds pvt. ltd, Hosur branch) of Venkateshwara Hatcheries Private Limited, Pune. Chicks were individually weighed, wing banded and randomly allotted into 10 different treatment groups, with three replicates. Each replicate had 10 chicks and thus, 30 birds constituted a treatment group.

The birds were reared in brooder cum grower cages up to six weeks of age. Incandescent bulbs of 60watt capacity (electrical brooding) were utilized for maintaining the temperature during the brooding period. The lighting regimen practiced was $24 \mathrm{~h}$ light: $0 \mathrm{~h}$ dark during the brooding period. An adequate care was taken to provide optimum and uniform managemental conditions to all the treatments groups. Linear feeders and circular drinkers were kept inside the cages to provide sufficient feeding and watering space for the birds.

All the chicks were vaccinated against Ranikhet disease, RDVF on $7^{\text {th }}$ and LaSota on $28^{\text {th }}$ day of age and Infectious Bursal Disease (Intermediate Strain) on $14^{\text {th }}$ day of age. The prestarter, starter and finisher rations prepared in Central Feed Technology Unit (TANUVAS), Kattupakkam (Kancheepuram Dt. Tamil Nadu, India) were fed to chicks during the experimental period. The experimental diets were prepared with or without different source of $\mathrm{Zn}$ as feed 
supplement as per the inclusion levels mentioned in the following Table-1.

The broiler pre-starter (PBS) mash was fed to the birds during first two weeks followed by starter (BS) mash up to four weeks of age and broiler finisher (BF) mash thereafter (5-6 weeks) as per BIS 2007 recommendations. During the period of study period (0-6 weeks), all the birds were provided with $a d$ libitum feed and water.

\section{Carcass characteristics}

At the end of 6th week of age, two birds from each replicate were taken randomly for the recording of carcass characteristics. Birds were dressed, eviscerated and the per cent eviscerated carcass yield, ready-to-cook yield and cut up yields were estimated.

The following parameters were recorded at the time of slaughter.

Pre-slaughter live weight (g)

Eviscerated weight without giblet Evisceration yield $(\%)=---------------\times 100$

Pre-slaughter live weight

Eviscerated weight with giblet Ready-to-cook yield $(\%)=$-------------- $\times 100$

Pre-slaughter live weight

Weight of the individual cut-up part Cut-up parts yield $(\%)=$ $\times 100$

Eviscerated carcass weight

\section{Measurement of bone osteomorphometry}

During the slaughter study, the left tibia bone was dissected out from the birds and their adhering muscles together with connective tissue were removed manually to study the bone morphometric parameters. The bones were processed by dipping in $10 \%$ sodium hydroxide $(\mathrm{NaOH})$ solution for five minutes to remove the adhering fine and soft tissue. These bones were dried in hot air oven overnight and the bone measurements were taken with the vernier calliper as shown in Figure 1. De-fattening of dried bones was done with diethyl ether and petroleum sprit following the procedure of AOAC (2000). The weight of each tibia was determined as such using an electronic digital balance of $0.01 \mathrm{~g}$ accuracy and fat free dried basis.

\section{Statistical analysis}

The data collected on various parameters were grouped and subjected for statistical analysis of variance (ANOVA) as per the procedure of statistical package for social sciences (SPSS) software package for windows as per Snedecor and Cochran (1989). All the percent values in the experiment were transformed to their arcsine roots before subjecting to statistical analysis. Results were expressed as mean $\pm \mathrm{SE}$ and the difference were considered statistically significant at $\mathrm{P}<0.05$ and highly significant at $\mathrm{P}<0.01$.

\section{Results and Discussion}

The carcass characteristic (per cent eviscerated yield, ready-to-cook yield and giblet per cent) of broiler chicken under different treatments was presented in Table-2. Pre-slaughter live weight was ranged from $1945.33 \mathrm{gm}$ to $2063 \mathrm{gm}$. There was no significant $(p>0.05)$ difference observed between different sources of $\mathrm{Zn}$ supplemented (treatment groups) and unsupplement (control) groups. The eviscerated carcass weights $(\%)$ were ranged from $64.50 \%$ to $66.85 \%$. In the present study there was no significant difference $(\mathrm{p}>0.05)$ observed in the per cent carcass yield in Cobb broilers. It was observed that the supplementation of $\mathrm{Zn}$ either through $\mathrm{ZnSO}_{4}$ or through $\mathrm{Zn}$ protienate at a level of $40 \mathrm{ppm}$ showed 
numerically higher mean per cent eviscerated and ready-to-cook yield of 66.80 and 66.85; 71.97 and 71.56, respectively. Our results are in agreement with findings of Liu et al., (2011) and Yogesh et al., (2013) in broiler chickens. The present findings were in agreement with the findings of Vladimir et al., (2010) who found that groups fed with trace elements in proteinated form restricted to 50 per cent (on regular levels) $\mathrm{Cu}, 20$ per cent Fe, $\mathrm{Zn}$ and $\mathrm{Mn}$ and of Se had same effect on carcass yield.

The results of the present experiment was in agreement with Sunder et al.,(2008) who also found that supplemental $\mathrm{Zn}$ did not influence ready to cook yield in broilers. However, the present findings were in contrary with those of Ellen et al., (2012) who found that dressing percentage was significantly higher in group fed with $2.50 \mathrm{~g} / \mathrm{ton}, 11.25 \mathrm{~g} / \mathrm{ton}, 15.00 \mathrm{~g} / \mathrm{ton}$, and $18.75 \mathrm{~g} /$ ton of amino acid chelates of $\mathrm{Cu}$, $\mathrm{Zn}, \mathrm{Mn}$ and $\mathrm{Fe}$, respectively. The present findings were also in disagreement with the findings of Jahanian and Rasouli (2008) who indicated that dietary Zn-methionine inclusion in replacement of inorganic sources showed increased carcass meat yield. The present finding with respect to giblet were also in disagreement with that of Iqbal et al., (2011) who observed that broiler chickens fed with lower levels (40 mg) zinc from organic source when combined with different sources and concentrations of copper had significant effect on liver and heart weight. Similarly, Kumar et al., (2009) also reported that the carcass quality traits (dressing and eviscerated yield) of broiler chicken did not show any significant change due to supplementation of different $\mathrm{Zn}$ sources and levels.

Table.1 Inclusion levels of different $\mathrm{Zn}$ supplements in experimental diets

\section{S. No. Treatment Supplemental Zn source $\quad$ Zn (ppm) level in the feed}

\begin{tabular}{cccc}
\hline 1. & $\mathrm{T} 1$ & Control (un-supplemented with zinc) & - \\
2. & $\mathrm{T} 2$ & Zinc oxide & 40 \\
3. & $\mathrm{T} 3$ & Zinc oxide & 80 \\
4. & $\mathrm{T} 4$ & Zinc sulphate & 40 \\
5. & $\mathrm{T} 5$ & Zinc sulphate & 80 \\
6. & $\mathrm{T} 6$ & Zinc-methionine & 40 \\
7. & $\mathrm{T} 7$ & Zinc-methionine & 80 \\
8. & $\mathrm{~T} 8$ & Zinc-proteinate & 40 \\
9. & $\mathrm{~T} 9$ & Zinc-proteinate & 80 \\
10. & $\mathrm{T} 10$ & Nano-zinc & 20 \\
\hline
\end{tabular}


Table.2 Effect of different dietary zinc sources as a feed supplements on carcass characteristics and Giblet (\%) in commercial broiler Chicken $($ Mean \pm SE) $(n=60)$

\begin{tabular}{|c|c|c|c|c|c|c|}
\hline \multirow{2}{*}{$\begin{array}{l}\text { Treatments } \\
\text { (in ppm) }\end{array}$} & \multicolumn{3}{|c|}{ Carcass characteristics } & \multicolumn{3}{|c|}{ Giblet (\%) } \\
\hline & $\begin{array}{c}\text { Live weight } \\
\text { (g) }\end{array}$ & Eviscerated weight (\%) & $\begin{array}{c}\text { Ready-to-cook yield } \\
(\%)\end{array}$ & Heart & Liver & Gizzard \\
\hline T1Control & $\begin{array}{c}2063.00 \pm \\
95.89\end{array}$ & $66.63 \pm 0.79$ & $71.91 \pm 0.72$ & $0.61 \pm 0.06$ & $1.88 \pm 0.09$ & $2.79 \pm 0.19$ \\
\hline $\mathrm{T} 2 \mathrm{ZnO}-40$ & $\begin{array}{c}2056.67 \pm \\
72.11 \\
\end{array}$ & $64.50 \pm 1.44$ & $69.29 \pm 1.40$ & $0.54 \pm 0.03$ & $1.81 \pm 0.07$ & $2.44 \pm 0.11$ \\
\hline T3ZnO - 80 & $\begin{array}{l}2009.67 \\
\pm 124.89 \\
\end{array}$ & $66.29 \pm 0.98$ & $71.37 \pm 0.98$ & $0.52 \pm 0.03$ & $1.94 \pm 0.10$ & $2.61 \pm 0.10$ \\
\hline 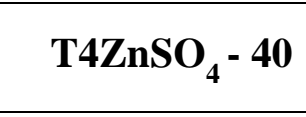 & $\begin{array}{c}2024.67 \pm \\
64.29 \\
\end{array}$ & $66.80 \pm 0.77$ & $71.97 \pm 0.64$ & $0.54 \pm 0.05$ & $1.88 \pm 0.13$ & $2.76 \pm 0.31$ \\
\hline $\mathrm{T}^{2} \mathrm{ZnSO}_{4}-80$ & $\begin{array}{l}2002.67 \\
\pm 101.97\end{array}$ & $65.70 \pm 0.63$ & $70.77 \pm 0.61$ & $0.50 \pm 0.02$ & $1.78 \pm 0.12$ & $2.80 \pm 0.16$ \\
\hline T6ZnMet - 40 & $\begin{array}{c}1996.67 \pm \\
83.75\end{array}$ & $65.57 \pm 0.68$ & $70.77 \pm 0.68$ & $0.55 \pm 0.05$ & $1.76 \pm 0.14$ & $2.90 \pm 0.12$ \\
\hline T7ZnMet - 80 & $\begin{array}{c}1955.67 \pm \\
43.91\end{array}$ & $65.12 \pm 0.42$ & $70.32 \pm 0.54$ & $0.53 \pm 0.05$ & $1.72 \pm 0.06$ & $2.96 \pm 0.18$ \\
\hline T8ZnP - 40 & $\begin{array}{c}1971.33 \pm \\
80.09\end{array}$ & $66.85 \pm 0.80$ & $71.56 \pm 0.85$ & $0.49 \pm 0.02$ & $1.70 \pm 0.07$ & $2.52 \pm 0.18$ \\
\hline T9ZnP - 80 & $\begin{array}{c}1991.67 \pm \\
35.88\end{array}$ & $66.28 \pm 1.15$ & $71.17 \pm 0.98$ & $0.54 \pm 0.04$ & $1.72 \pm 0.07$ & $2.62 \pm 0.12$ \\
\hline T10Nano Zn & $\begin{array}{c}1945.33 \pm \\
67.61\end{array}$ & $65.68 \pm 0.96$ & $71.06 \pm 0.86$ & $0.52 \pm 0.03$ & $1.83 \pm 0.06$ & $3.03 \pm 0.17$ \\
\hline F value & 0.232 & 0.719 & $\mathbf{0 . 8 3 7}$ & 0.646 & 0.761 & 1.234 \\
\hline Significance & & & Not significant $(\mathrm{P}>0 . \mathrm{C}$ & & & \\
\hline
\end{tabular}


Table.3 Effect of different dietary zinc sources as a feed supplement on cut-up-parts (\%) at sixth week of age in commercial broiler Chicken (Mean \pm SE) $(n=60)$

\begin{tabular}{|c|c|c|c|c|c|c|}
\hline \multirow{2}{*}{$\begin{array}{c}\text { Treatments } \\
\text { (in ppm) }\end{array}$} & \multicolumn{6}{|c|}{ Cut-up-parts (\%) } \\
\hline & Brest & Drumstick & Wing & Neck & Back & Thigh \\
\hline T1 Control & $34.54 \pm 0.95$ & $16.02 \pm 0.52$ & $10.09 \pm 0.34$ & $3.83 \pm 0.17$ & $21.73 \pm 0.63$ & $14.01 \pm 0.30$ \\
\hline $\mathrm{T} 2 \mathrm{ZnO}-40$ & $35.56 \pm 0.59$ & $16.01 \pm 0.25$ & $9.20 \pm 0.21$ & $3.76 \pm 0.20$ & $21.27 \pm 0.40$ & $13.74 \pm 0.34$ \\
\hline T3 ZnO - 80 & $35.36 \pm 0.24$ & $16.68 \pm 0.29$ & $9.12 \pm 0.29$ & $3.61 \pm 0.19$ & $21.89 \pm 0.33$ & $13.00 \pm 0.36$ \\
\hline $\mathrm{T}^{2} \mathrm{ZnSO}_{4}-40$ & $34.79 \pm 0.53$ & $15.80 \pm 0.70$ & $10.06 \pm 0.32$ & $4.12 \pm 0.30$ & $21.66 \pm 0.31$ & $13.48 \pm 0.30$ \\
\hline $\mathrm{T} 5 \mathrm{ZnSO}_{4}-80$ & $33.15 \pm 0.94$ & $17.30 \pm 0.43$ & $9.40 \pm 0.34$ & $3.81 \pm 0.14$ & $21.43 \pm 0.51$ & $14.94 \pm 0.35$ \\
\hline T6 ZnMet - 40 & $34.04 \pm 0.58$ & $17.47 \pm 0.20$ & $9.17 \pm 0.27$ & $3.81 \pm 0.11$ & $21.15 \pm 0.77$ & $14.37 \pm 0.45$ \\
\hline T7 ZnMet - 80 & $34.66 \pm 0.54$ & $16.99 \pm 0.31$ & $8.80 \pm 0.18$ & $3.81 \pm 0.12$ & $22.12 \pm 0.23$ & $13.69 \pm 0.17$ \\
\hline T8 ZnP - 40 & $34.97 \pm 0.60$ & $16.49 \pm 0.46$ & $8.78 \pm 0.29$ & $3.77 \pm 0.14$ & $21.22 \pm 0.45$ & $14.04 \pm 0.35$ \\
\hline T9 ZnP - 80 & $34.75 \pm 0.79$ & $16.68 \pm 0.21$ & $9.218 \pm 0.24$ & $3.93 \pm 0.18$ & $20.65 \pm 0.58$ & $14.00 \pm 0.34$ \\
\hline T10 Nano Zn & $36.16 \pm 0.58$ & $17.24 \pm 0.37$ & $9.09 \pm 0.21$ & $4.14 \pm 0.20$ & $20.21 \pm 0.61$ & $13.47 \pm 0.20$ \\
\hline F value & 1.562 & 1.132 & 1.619 & 0.788 & 1.305 & 1.690 \\
\hline Significance & NS & $\mathbf{N S}$ & NS & NS & $\mathbf{N S}$ & $\mathbf{N S}$ \\
\hline
\end{tabular}

Table.4 Effect of different dietary zinc sources as a feed supplement on dry bone weight $(\mathrm{g})$, bone length $(\mathrm{cm})$ and diameter $(\mathrm{cm})$ at Sixth week of age in commercial broiler chicken (Mean \pm SE) $(n=60)$

\begin{tabular}{|c|c|c|c|c|}
\hline Treatments (in ppm) & Dry bone weight (g) & Bone length (cm) & Bone diameter (cm) & Total ash (\%) \\
\hline T1Control & $6.94 \pm 0.36$ & $9.48 \pm 0.01$ & $1.12 \pm 0.23$ & $49.05 \pm 0.91$ \\
\hline T2ZnO - 40 & $6.87 \pm 0.39$ & $9.60 \pm 0.13$ & $1.08 \pm 0.24$ & $47.26 \pm 1.06$ \\
\hline T3ZnO - 80 & $6.93 \pm 0.60$ & $9.72 \pm 0.17$ & $1.10 \pm 0.03$ & $47.36 \pm 0.73$ \\
\hline $\mathrm{T}^{2} \mathrm{ZnSO}_{4}-40$ & $6.51 \pm 0.18$ & $9.71 \pm 0.14$ & $1.04 \pm 0.13$ & $49.01 \pm 0.75$ \\
\hline $\mathrm{T}^{2} \mathrm{ZnSO}_{4}-80$ & $6.75 \pm 0.35$ & $9.87 \pm 0.27$ & $1.09 \pm 0.02$ & $48.29 \pm 1.46$ \\
\hline T6ZnMet - 40 & $6.95 \pm 0.59$ & $9.53 \pm 0.16$ & $1.10 \pm 0.03$ & $47.97 \pm 0.93$ \\
\hline T7ZnMet - 80 & $7.35 \pm 0.50$ & $9.51 \pm 0.12$ & $1.08 \pm 0.12$ & $49.20 \pm 1.24$ \\
\hline T8ZnP - 40 & $7.31 \pm 0.81$ & $9.76 \pm 0.19$ & $1.11 \pm 0.04$ & $48.25 \pm 1.39$ \\
\hline T9ZnP - 80 & $6.90 \pm 0.30$ & $9.73 \pm 0.13$ & $1.10 \pm 0.03$ & $48.77 \pm 1.48$ \\
\hline T10Nano Zn & $6.40 \pm 0.30$ & $9.66 \pm 0.12$ & $1.08 \pm 0.02$ & $48.39 \pm 0.90$ \\
\hline F value & 0.397 & 0.619 & 0.576 & 0.619 \\
\hline Significance & \multicolumn{4}{|c|}{ NS - Not significant $(\mathrm{P}>0.05)$} \\
\hline
\end{tabular}


Fig.1 Preparation of bones for osteomorphometry study

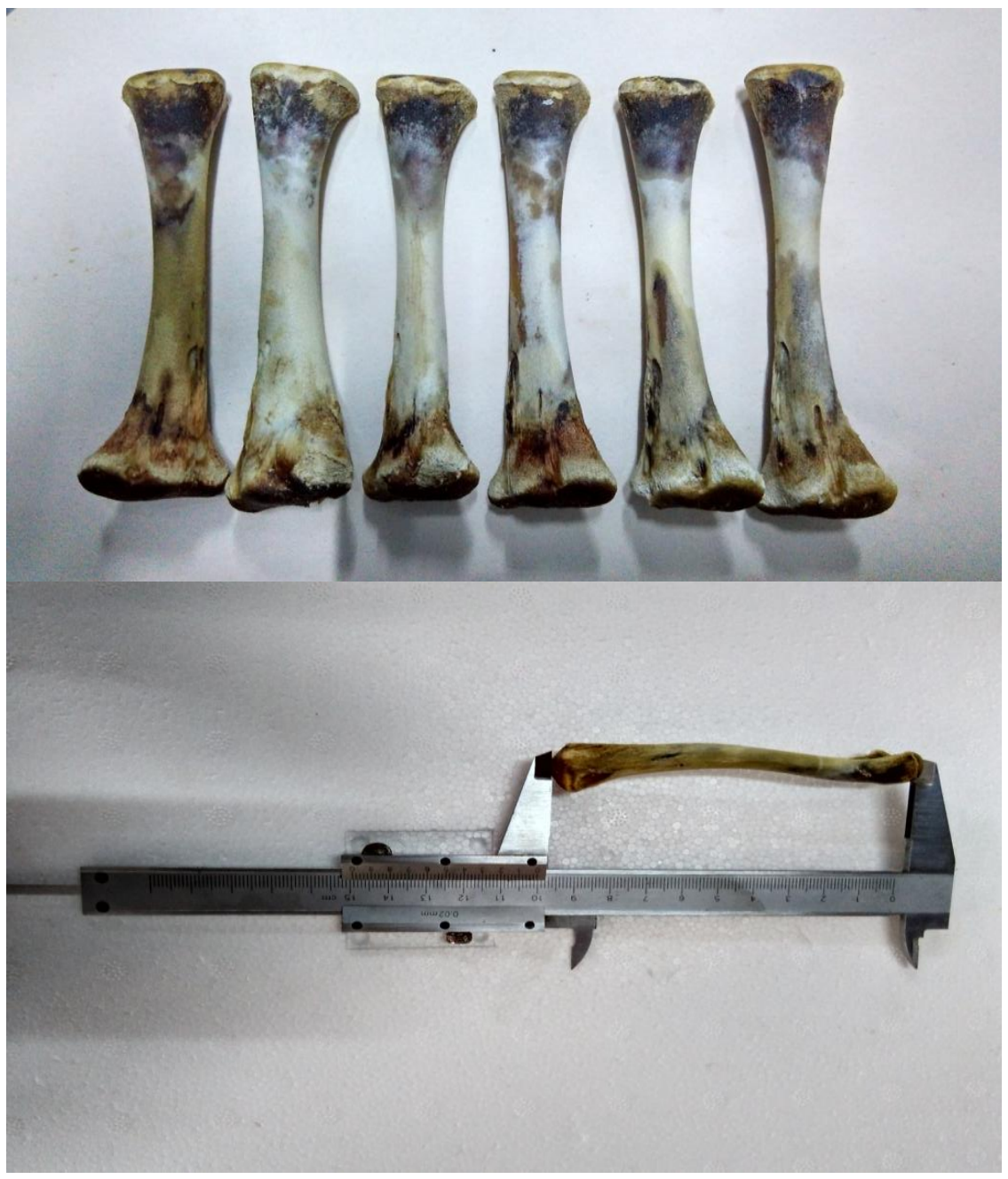

The per cent cut-up parts of broiler chicken under different treatments were presented in Table-3. Saenmahayak et al., (2010) reported that feeding of organic or chelated trace minerals resulted in a better breast meat yield which was in disagreement with the present findings, showed that no significant $(\mathrm{p}>0.05)$ difference in breast meat yield upon organic and inorganic $\mathrm{Zn}$ supplementation.

There was no significant $(\mathrm{p}>0.05)$ difference observed in the bone morphometric studies with respect to bone weight $(\mathrm{g})$, bone length $(\mathrm{cm})$, bone diameter $(\mathrm{cm})$ and total ash $(\%)$ in Cobb broilers under study as shown in Table4. The present findings were in agreement with the findings of Bao et al., (2010) who reported that addition of all 4 trace minerals $(\mathrm{Cu}, \mathrm{Fe}, \mathrm{Mn}$ and $\mathrm{Zn})$ to the control diet did not improve $(\mathrm{P}>005)$ total tibia trace mineral content and tibia bone quality (tibia length and width). The present findings were in agreement with the result of Oliveira et al., (2015) who reported that there was no significant effect noted for dry tibia weights, tibia length and width, tibia length to weight ratio $(\mathrm{L} / \mathrm{W})$, when the birds fed with organic sources of $\mathrm{Zn}, \mathrm{Mn}$ and $\mathrm{Cu}$. The present findings were also in disagreement with the findings of Osama et al., (2012) who reported that birds fed with $50 \% \mathrm{Zn}+50 \% \mathrm{Mn}+50 \% \mathrm{Cu}$ (organic) diet showed improved tibia weight, 
length, diaphysis diameter, weight/length index. This might be due to that the birds were sacrificed at 32 days of age whereas, the current study the birds were slaughtered at $42^{\text {nd }}$ day. Soni et al., (2014) observed that physical parameters of tibia bone such as weight, length and cortex thickness in different dietary treatments of zinc did not show any significant change. There was a lack of literature on effect of supplementation of nano zinc on bone physical parameters, however in the present study nano $\mathrm{Zn}$ supplementation did not showed any significant change in the bone physical parameters.

It was concluded that the dietary supplementation of inorganic, organic and nano $\mathrm{Zn}$ did not show any significant change in the percentage of carcass yield and bone morphometric parameters in the commercial broiler chicken.

\section{References}

AOAC, 2000. Official methods of analysis of AOAC International, (17th ed.), Gaithersburg, MD, USA: AOA.

Bao, Y. M., Choct, M., Iji, P. A., and Bruerton, K. 2010. Trace mineral interactions in broiler chicken diets.British poultry science,51(1), 109-117.

BIS, 2007. Indian standard poultry feeds specifications. $5^{\text {th }}$ revision IS: 1374 , ManakBhavan, 9, Bahadur Shah ZaferMarg, New Delhi. p.7.

Ellen, B., Britanico, Florinia, Merca, E., Amado, Angeles, Sonia, A., Acda, P and Edwin, S. Luis. 2012. Effects of supplementing diets with amino acid chelates of copper, zinc, manganese and iron on the performance of broilers. Philipp. J. Vet. Anim. Sci. 38(1): 1-10.

Iqbal, S., Deo, C., Mandal, A. B., Tyagi, P. K., andAwachat, V. B. 2011. Response of feeding different sources and concentrations of zinc and copper on performance of broiler chickens.Indian J. Poult. Sci., 46(3), 330-336.

Jackson, B.P., Bertsch PM, Cabrera ML, Camberato JJ, Seaman JC and Wood CW 2003. Trace element speciation in poultry litter. Journal of Environmental Quality, 32: 535-540.

Jahanian, R., Moghaddam, H. N., andRezaei, A. 2008. Improved broiler chick performance by dietary supplementation of organic zinc sources. Asian-Aust. J. Anim. Sci, 21(9), 1348-1354.

Kumar, Y., Deo, C., Shrivastava, H.P., Madal, A.B. and Mishra, S.K. 2009. Response of feeding different sources and concentrations of zinc on growth, immune response and carcass yield of broiler chicks. Proceedings of Animal Nutrition Association World Conference, 14- 17 Feb., 2009, New Delhi, India.

Leeson, S., 2003. A new look at trace mineral nutrition of poultry: Can we reduce the environmental burden of poultry manure? Pp 125-129 Nutritional biotechnology in the feed and food industries. Proc. Alltech's 19th Annu. Symp. T. P. Lyons and K. A. Jacques, Ed. Nottingham Univ. Press, Nottingham, UK.

Liu, Z. H., Lu, L., Li, S. F., Zhang, L. Y., Xi, L., Zhang, K. Y., and Luo, X. G. 2011. Effects of supplemental zinc source and level on growth performance, carcass traits, and meat quality of broilers. Poultry science, 90(8), 17821790.

Oliveira, T. F. B., Bertechini, A. G., Bricka, R. M., Kim, E. J., Gerard, P. D., and Peebles, E. D. 2015. Effects of in ovo injection of organic zinc, manganese, and copper on the hatchability and bone parameters of broiler hatchlings. Poultry science, pev248. 
Osama, M., El-Husseiny, Hashish, S. M., Ali, R. A., Arafa, S. A., Abd El-Samee, L. D., and Olemy, A. A. 2012. Effects of feeding organic zinc, manganese and copper on broiler growth, carcass characteristics, bone quality and mineral content in bone, liver and excreta. International Journal of Poultry Science, 11(6), 368-377.

Raji Reddi Kesireddy, 2014. Poultry Market likely to see double digit growth in 2015. Economic Times Bureau, December 25, 2014.

Saenmahayak, B., Bilgili, S. F., Hess, J. B., and Singh, M. 2010. Live and processing performance of broiler chickens fed diets supplemented with complexed zinc. J ApplPoult Res. 19(4), 334-340.

Snedecor, G.W., and Cochran, W.G. 1989. Statistical Methods. 8th ed. IowaState University Press, Ames, Iowa.

Song, S., Qin, Y., He, Y., Huang, Q., Fan, C., and Chen, H. Y. 2010. Functional nanoprobes for ultrasensitive detection of biomolecules. Chemical Society Reviews, 39(11), 4234-4243.

Soni, N., Mishra, S. K., Swain, R. K., Das, A.,
Behura, N. C., and Sahoo, G. 2014. Effect of supplementation of organic zinc on the performance of broiler breeders. Animal Nutrition and Feed Technology, 14(2), 359-369.

Sunder, G. S., Panda, A. K., Gopinath, N.C.S., Rao, S.V.R., Raju, M., Reddy, M. R. and. Kumar, C.V., 2008. Effects of higher levels of zinc supplementation on performance, mineral availability, and immune competence in broiler chickens. J. Appl. Poult. Res. 17:79-86.

Vladimir Petrovic, Lode Nollet and Gabriel Kovac. 2010. Effect of dietary supplementation of trace elements on the growth performance and their distribution in the breast and thigh muscles depending on the age of broiler chickens. Acta. Vet.79: 203-209.

Yogesh, K., Deo, C., Shrivastava, H. P., Mandal, A. B., Wadhwa, A., and Singh, I. 2013. Growth performance, carcass yield, and immune competence of broiler chickens as influenced by dietary supplemental zinc sources and levels. Agricultural Research,2(3), 270-274.

\section{How to cite this article:}

Varun A., N. Karthikeyan, P. Muthusamy, A. Raja, S. Wilfred Ruban and Tamilkumaran J. 2017. Carcass Characteristics and Bone Measurements of Commercial Broilers Fed with Inorganic, Organic and Nano Zn Containing Diets. Int.J.Curr.Microbiol.App.Sci. 6(9): 37483756. doi: https://doi.org/10.20546/ijcmas.2017.609.363 